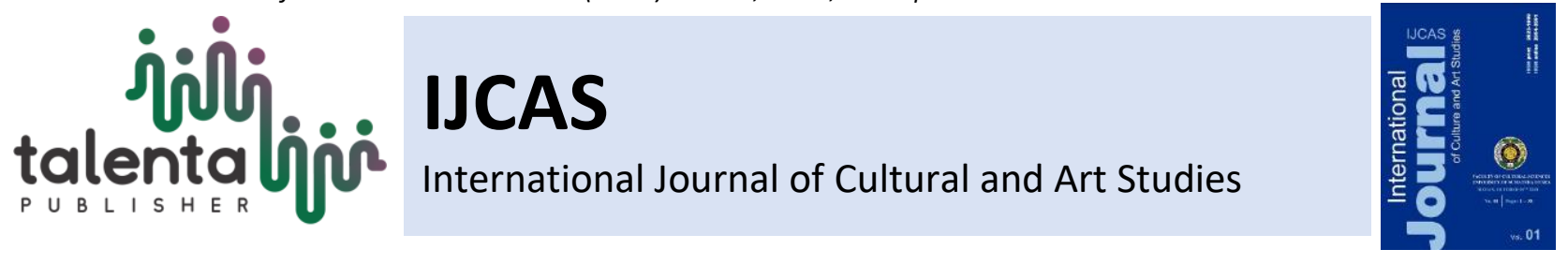

\title{
Languages in Contact: A Study of Arabic Loanwords in Malay/Indonesian Language
}

\author{
Rozanna Mulyani ${ }^{1 *}$, Noordin Mohd Noor ${ }^{2}$ \\ Universitas Sumatera Utara ${ }^{I}$ \\ Universiti Sains Malaysia ${ }^{2}$
}

\begin{abstract}
This paper discusses the contact language between Malay and Arabic language. Objectives of the study are to look into the etymology similarities on national language between two countries. This paper applied qualitative analysis, which is based on discussions and comparisons. The results of this study showed that cultural contact, especially the reach of Islam in Southeast Asia results in linguistic contact. Linguistic borrowing in most cases exhibits as a response to language borrowing. A number of motivations stand behind the phenomenon of borrowing. There are many Arabic words assimilating into Malay language as a result of cultural and linguistic contact between Malay language as a lingua franca of the region in the early days and Arabic language.
\end{abstract}

Keywords: Arabic Language, Language Contact, Malay Language

Received 15 May 2018 | Revised 25 July 2018 | Accepted 20 August 2018

\section{Introduction}

Malay language is a major language in Southeast Asia. Malay language has undergone through various stages of development that derived from different layers of foreign languages influencing many activities such as international trade, religious expansion, colonization and development of recent socio-political trends. The oldest form of Malay language is believed descended from the Proto-Malayo-Polynesian language spoken by the earliest Austronesian settlers in Southeast Asia. This form would later evolve into Old Malay language when Hindu-Buddhism culture and religion began penetrating the region. Old Malay language contained some Sanskrit terms that exist today and perhaps are unintelligible to current Malay language speakers. On the other hand, the modern Malay language form is recognizable in written Classical Malay language.

Classical Malay language undergoes the gradual borrowing of numerous Arabic vocabularies. It happened when Islam made its way to the region. Initially, Classical Malay language was a diverse group of dialects, reflecting the varied origins of the Malay kingdoms in the Southeast

\footnotetext{
*Corresponding author at: Department of Malay Literature, Faculty of Cultural Sciences, University of Sumatra Utara, Medan, Indonesia 20155.

E-mail address: rozanna.mulyani@usu.ac.id
} 
Asia. One of these dialects that was developed in the literary tradition of Melaka Sultanate in the 15th century eventually became predominant. The strong influence of Melaka Sultanate in international trade in the region resulted in Malay as a lingua franca in commerce and diplomacy, a status that was maintained throughout the age of the succeeding Malay sultanates, the European colonial era and the modern times.

The study Arabic loan words in Malay and Indonesian Language has done individually by a scholar like J. Russell (1978) [1] and M.A.J Beg (1977) [2]. Jones claims that his works focused on Indonesian language, whereas Beg collects Arabic studied words found in Malay language, Urdu and few others. This study is different hence it is a collaboration of two scholars from Malaysia and Indonesia. Definitely, there are some new angles to be discussed in this study.

\section{Objectives}

Objectives of the study are to look into the etymology similarities of national language between two countries. Malay language in Malaysia known as Bahasa Kebangsaan or Standard Malay language. In Singapore and Brunei, it is called Bahasa Melayu (Malay language); in Malaysia as Bahasa Malaysia. In Indonesia, this language is called Bahasa Indonesia (Indonesian language). The choice to use Bahasa Indonesia involves political home affairs reasons for the purpose of "unifying language" (Bahasa Persatuan/Pemersatu).

In general, some Indonesians (not linguistically speaking) refer and consider Bahasa Melayu is just one of their regional languages, Bahasa Indonesia is not Bahasa Melayu. However, in Malaysia generally refer or consider Bahasa Indonesia is just another form of Malay language, or Malay language with Indonesian accent (bahasa Melayu loghat/lenggok/cengkok Indonesia). This is similar to the case of British English and American English.

Furthermore, Malay magnum opus literary works such as Hikayat Hang Tuah, Sulalatus Salatin, Hikayat Raja-raja Pasai (just to name a few) have united Malaysia and Indonesia. The works crossed the political territorial boundary of the two or more countries. Besides the language, the usage of Jawi scriptures also will make the people come to some sorts of agreement that Malaysia and Indonesia share the same values regarding national language. The scenario of Indonesia and Malaysia, when Malaysian and Indonesian use their national language, the parts that can be understood are much bigger. Therefore, it is better to reconsider whether it is true or not the statement that Indonesian language is very different from the Malay language in which the root of both languages is the same. It can possibly describe that the stance was influenced by national political mind. [3] 


\section{Limitation}

This study was limited to the selected Arabic words only. These selected words are basic words that maintain or retain the same meaning as in Arabic. Derivative verb that borrowed from Arabic are not discussed due to these matters will definitely involve other disciplines of linguistics approaches.

\section{Research Methodology}

This paper implemented qualitative analysis method based on discussions and comparison. In terms of resource, this paper involved the analysis of the contents of the dictionary as a unit of analysis of the study to evaluate the assimilation of Arabic words according to the classification of words. Dictionaries as a unit of analysis for this study are Kamus Dewan (KD) [4] and Kamus Besar Bahasa Indonesia (KBBI) [5] that contain Arabic words in Malay/Indonesia Language. The words further were analysed by using a Malay Language-Jawi glossary and Daftar Kata Bahasa Melayu Rumi-Sebutan-Jawi (DBKM) [6] that contain the Arabic spelling of words in Jawi writing. For the purposes of the discussions, some Arabic words which have been assimilated into the Malay language either marked with the abbreviation "Ar" in KD or not (because of its strong use of the Malay language) were included. Further analysis on the types of assimilating words whether these words have fully assimilated (spelling preserved) or changed (spelling) will not be discussed because it can lead to another research.

\section{Discussions}

\subsection{The Influence of Arabic Loanwords in Malay Names}

Malay people are identic with Muslims. In general, Muslim Malay men and women will use Arabic names. Mostly the name selected are taken from prophets' names and the names have good meanings. For examples:

- Adam, Hawa, Idris, Nuh, Soleh, Ibrahim, Ismail, Yaakub, Isa Muhammad, etc.

- Mariam, Siti Hajar, Siti Fatimah, Khadijah, Aminah, etc.

- The names that start with Nur such as Nurhayati, Nuraini, Nurhaliza, etc.

- The names started with Ahmad and Muhammad such as Ahmad Yani, Ahmad Dani, Ahmad Daud, Muhammad Nur, Muhammad Yamin, Muhammad Lukman, etc.

\subsection{Arabic Loanwords for Days in a Week}

\begin{tabular}{|c|c|}
\hline - Senin-Isnin & = Monday \\
\hline - Selasa & $=$ Tuesday \\
\hline
\end{tabular}




$\begin{array}{lll}\text { - Rabu } & \text { = Wednesday } & \\ \text { - Kamis- Khamis } & =\text { Thursday } & \text { خميس } \\ \text { - Jumat-Jumaat } & =\text { Friday } & \\ \text { - Sabtu } & =\text { Saturday } & \end{array}$

Ahad for Sunday الأحد، is a word actively used in Malaysia, Singapore and Brunei, but Indonesia uses Minggu for Sunday. Names of day are actually originally from numerical counting system in Arabics:

- One = Wahid (become Ahad)

الأحد

- Two = Ithnain/Isnain

، الإثنين

- Three $=$ Thalatha $/$ Selasa

لثناثاء،

- Four = Arba'a/Rabu

الأربعاء

- Five $\quad=$ Khamsa/Khamis/Kamis

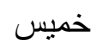

\subsection{Others}

Arabic words exist in various areas or parts of Malay/Indonesian language, for examples the words such as hukum, hakim, adil contributing to law terms. In education term, it can be found the words like kuliah, madrasah, telaah, ilmu alamiah, etc. Daily spoken word such as hadir, kerusi, kemeja, wasit, wali, syukur, doa, ruh, etc. It is undeniable that Arabic has contributed to the vocabulary of the Malay language in the region.

\section{Conclusion}

Cultural contact, especially the reach of Islam in Southeast Asia results in linguistic contact. Linguistic borrowing in most cases exhibits as a response to language borrowing. A number of motivations stand behind the phenomenon of borrowing. As a result of cultural and linguistic contact between Malay language as a lingua franca of the region in the early days and Arabic languages, there are many Arabic words assimilating into Malay languages. This is just a small scope of study. The study of loanwords can be expanded in accordance to the linguistic system of the receptor of language in many other disciplines such as phonology, morphology, and semantics. 


\section{REFERENCES}

[1] J. Russel. Loan Words in Indonesian and Malay. Indonesian Etymological Project, KITCV Office Jakarta. Jakarta: Yayasan Obor Indonesia, 2008.

[2] M.A.J. Beg, Arabic Loanwords in Malay. A Comparative Study, Kuala Lumpur: Sally Printing Service, 1977.

[3] H. Alwi eds, Tata Bahasa Baku Bahasa Indonesia, Jakarta: Balai Pustaka, 1999.

[4] , Kamus Dewan, Fourth Edition, Kuala Lumpur: Dewan Bahasa dan Pustaka, 2005.

[5] ___ Kamus Besar Bahasa Indonesia, Third Edition. Jakarta: Balai Pustaka, 2002.

[6] ___ _ Daftar Kata Bahasa Melayu, Kuala Lumpur: Dewan Bahasa dan Pustaka, 2008.

[7] A. Kasimin, Perbendaharaan Kata Arab dalam Bahasa Melayu, Bangi: Penerbit Universiti Kebangsaan Malaysia, 1987.

[8] N. Armstrong, Translation, Linguistics, Culture: A French-English Handbook, Clevedon, Buffalo and Toronto: Multilingual Matters Ltd., 2005.

[9] Asmah Hj. Omar, Bahasa Malaysia Saintifik, Kuala Lumpur: Dewan Bahasa dan Pustaka, 1987a.

[10] __. Malay Lexicography: An Assessment, Kertas Lecture Paper Rememberance of the Tenth Anniversary of the National Collection, Universiti Malaya Library, 1987.

[11] L. Bloomfield, Language, London: George Allen \& Unwin Ltd., 1933.

[12] C. Crawford, Adaptation and Transmission in Japanese Loanword Phonology, United States - New York: Cornell University, 2009.

[13] C. H. L. Heah, The Influence of English on The Lexical Expansion of Bahasa Malaysia, Kuala Lumpur: Dewan Bahasa dan Pustaka, 1989.

[14] H. Kridalaksana, "Lexicology and Lexicography, "in Fundamentals of Lexicology and Lexicography: Bilingual Dictionary Compilation Training Materials (Indonesia/MalayForeign, Indonesia/Malay-Daerah), Depok: Fakultas Ilmu Pengetahuan Budaya, Universitas Indonesia, 2007.

[15] Nik Safiah Karim. Bimbingan Pelajar Bahasa Kita, Jilid 1, Shah Alam: "K" Publishing, 2003.

[16] ___ Tata bahasa Dewan, Kuala Lumpur: DBP, 2008. 